\title{
Tolerogen-Producing Cells in Allogeneic Bone Marrow Chimeras Established with Spontaneously Leukemia-Prone Mice
}

\author{
Machiko Mishimai), Mari Hirano1), Taiki Morohashi' ${ }^{1)}$, Noriko Arase ${ }^{1)}$, \\ Hayase Shisa $^{2)}$, Hiroshi Hiai ${ }^{3)}$, Manabu Ato ${ }^{1)}$ and Kazunori Onoé ${ }^{1)}$ \\ ${ }^{1)}$ Division of Immunobiology, Institute for Genetic Medicine, Hokkaido University \\ ${ }^{2)}$ Laboratory of Basic Cancer Study, Saitama Cancer Center Research Institute \\ ${ }^{3}$ Department of Pathology and Biology of Diseases, Graduate School of Medicine, Kyoto University
}

Using SL/Kh mice and $\mathrm{AKR} / \mathrm{J}$ mice, which are animal models for spontaneous pre-B-cell leukemia and thymic lymphoma, respectively, we studied the protective influence of allogeneic bone marrow transplantation (BMT) and the induction of tolerance to Mls- $1^{\mathrm{a}}$, a host antigen. When BM cells from allogeneic C57BL/6 mice were used to reconstitute self-tolerance $\mathrm{SL} / \mathrm{Kh}$ mice, these $[\mathrm{B} 6 \rightarrow \mathrm{SL}]$ chimeric mice survived for a longer time than non-treated $\mathrm{SL}$ or $[\mathrm{SL} \rightarrow \mathrm{SL}]$ syngeneic chimeras. These findings are compatible with results previously obtained for $[\mathrm{B} 6 \rightarrow \mathrm{AKR}]$ chimeras. In $[\mathrm{B} 10 . \mathrm{D} 2 \rightarrow \mathrm{SL}]$ and $[\mathrm{B} 10 . \mathrm{D} 2 \rightarrow \mathrm{AKR}]$ chimeras, $\mathrm{V} \beta 6^{+} \mathrm{T}$-cells reactive to $\mathrm{Mls}-1^{\text {a }}$ were eliminated 5 weeks after BMT. On the other hand, minor graft versus host reaction (GVHR) abrogated the clonal elimination of $\mathrm{V} \beta 6^{+} \mathrm{T}$-cells in both $[\mathrm{B} 10 . \mathrm{D} 2 \rightarrow \mathrm{SL}]$ and $[\mathrm{B} 10 . \mathrm{D} 2 \rightarrow \mathrm{AKR}]$ chimeras. The cause of this abrogation was attributed to the early disappearance of Mls-1 ${ }^{\mathrm{a}}$-producing host $\mathrm{T}$-cells in the GVHR chimeras. The cells responsible for the Mls-1 ${ }^{\text {a }}$ production were revealed to be mainly $\mathrm{CD} 8^{+} \mathrm{CD} 44^{+}$ $\mathrm{T}$-cells, by in vitro mixed lymphocyte reaction (MLR) and in vivo tolerance induction. The present findings indicate that host $\mathrm{CD} 8^{+} \mathrm{CD} 44^{+} \mathrm{T}$-cells constitute the major source of $\mathrm{Mls}-1^{\mathrm{a}}$ antigens in the $\left[\mathrm{Mls}-1^{\mathrm{b}} \rightarrow \mathrm{Mls}^{-} 1^{\mathrm{a}}\right]$ BM chimera system.

Key words allogeneic bone marrow chimera, minor lymphocyte stimulatory antigen $1^{\text {a }}$, negative selection, leukemia-prone mice

\section{INTRODUCTION}

T-cells undergo both negative and positive selections in the thymus ${ }^{1}$. To elucidate the selection mechanism, especially negative selection, the minor lymphocyte stimulatory (Mls)- $1^{\text {a }}$ antigen ( $\mathrm{Ag}$ ) system, an intrinsic super-antigen, has been widely employed. T-cell reactivity to $\mathrm{Mls}-\mathrm{I}^{\text {a }} \mathrm{Ag}$ correlates with the expression of certain $\mathrm{T}$-cell $\mathrm{Ag}$ receptor (TCR)- $\mathrm{Vb}$ regions $\mathrm{s}^{2,3}$. The expression of $\mathbf{M t v}^{-7}$, an endogenous mammary tumor virus gene which determines the $\mathrm{Mls}^{-1} 1^{\mathrm{a}}$ phenotype, results in the deletion among developing thymocytes, of T-cells that express $\mathrm{V} \beta 6, \mathrm{~V} \beta 7, \mathrm{~V} \beta 8.1$, or $\mathrm{V} \beta 9^{4-6}$. Using [Mls$\left.1^{\mathrm{b}} \rightarrow \mathrm{Mls}^{-} 1^{\mathrm{a}}\right]$ bone marrow $(\mathrm{BM})$ chimeras, we demonstrated that $\mathrm{Mls}^{-{ }^{\mathrm{a}}}{ }^{\mathrm{a}}$-reactive $\mathrm{T}$-cells are eliminated from the developing thymocyte population that is derived from the donor $\mathrm{BM}^{7,8}$. Further-

Received : December 27, 2000

Revised : February 5, 2001

Accepted: February 5, 2001 more, the presence of thymic stromal cells derived from the donor $\mathrm{BM}$ has been shown to be the primary requirement for the effective deletion of Mls- $1^{\mathrm{a}}$-reactive thymocytes ${ }^{7,9,10}$. We have reported that activated $\mathrm{CD} 8^{+}$and $\mathrm{CD} 4^{+} \mathrm{T}$-cells both produce Mls- $1^{\text {a }} \mathrm{Ag}$ in vitro, although only CD8 ${ }^{+} \mathrm{T}$-cells, not $\mathrm{CD}^{+}{ }^{+} \mathrm{T}$-cells, can produce $\mathrm{Mls}-1^{\mathrm{a}} \mathrm{Ag}$ under nonstimulated conditions ${ }^{11}$. Taking into account thatclonal deletion is a major mechanism for inducing and maintaining self-tolerance, it is important to determine the source of the relevant tolerogen in this chimera system, paying particular attention to the role of T-cells. In the present study, we first analyzed the protective influence of allogeneic bone marrow transplantation (BMT) in $\mathrm{SL} / \mathrm{Kh}$ mice, an animal model for pre-B-cell leukemia. We then analyzed which cell components in lethally irradiated recipient mice provides $\mathrm{Mls}^{-{ }^{-}}{ }^{\mathrm{a}} \mathrm{Ag}$ and ultimately contribute to clonal elimination of the $\mathrm{Mls}^{-1^{\mathrm{a}}}$ reactive $\mathrm{T}$-cell repertoire in the $\mathrm{BM}$ chimeric mice. We show here that the residual radio-resistant recipient $\mathrm{T}$-cells are the cells responsible for this intrath- 
M. Mishima, M. Hirano, T. Morohashi, N. Arase, 62

ymic clonal elimination.

\section{MATERIAL AND METHODS}

\section{Mice}

AKR/J (AKR) (H-2k Mls-1 $^{\mathrm{a}}$, Thyl.1) mice were obtained from the Jackson Laboratory (Bar Harbor, ME). C57BL/6 (B6) (H-2 $2^{\text {b }} \mathrm{Mls}^{-} 1^{\mathrm{b}}$, Thy 1.2), B10. BR/SgSnSlc (BR) $\left(\mathrm{H}^{-2}{ }^{\mathrm{k}}, \mathrm{Mls}^{-} 1^{\mathrm{b}}\right.$, Thy1.2), and B10. D2 (D2) (H-2 ${ }^{\mathrm{d}}$, Mls- ${ }^{\mathrm{b}}$, Thy1.2) mice were obtained from JAPAN SLC Co. (Hamamatsu, Japan). SL/Kh $(\mathrm{SL})\left(\mathrm{K}^{\mathrm{s}}, \mathrm{A}^{\mathrm{q}}, \mathrm{E}^{-}, \mathrm{Dq}\right)$ and $(\mathrm{AKR} \times \mathrm{BR}) \mathrm{F}_{1}$ mice were bred and maintained in our animal facility at Hokkaido University.

\section{Bone marrow transplantation}

Eight-week-old female AKR or SL mice were subjected to either 10 or 11 Gy X-ray irradiation. Twenty four hours later, these mice were treated to achieve hematopoietic and immunologic reconstitution with $2 \times 10^{7} \mathrm{BM}$ cells taken from 8-week-old B6, $\mathrm{D} 2$ or syngeneic mice. Prior to BMT, BM cells were treated in vitro with anti-Thy1.2 (F7D5, Olac, Bicester, $\mathrm{UK}$ ) monoclonal antibody $(\mathrm{mAb})$ plus selected rabbit complement $(C)^{12}$. To induce subclinical GVHR, BM cells treated with anti-Thyl.2 mAb alone were injected intravenously into the recipient mice $^{13-15}$. As reported earlier ${ }^{15}$, these GVHR chimeras scarcely showed overt signs of GVHR (ruffled fur, hunched back, significant loss of weight), but clonal elimination of self-reactive $T$ cells (i. e. against recipient's $\mathrm{Ag}$ ) was abrogated. Chimeras prepared by injecting T-cell-depleted BM cells alone will be referred to as [donor $\rightarrow$ recipient] chimeras or control chimeras. Chimeras which were given $\mathrm{BM}$ cells pretreated with anti-Thy $1.2 \mathrm{mAb}$ alone will be referred to as GVHR [donor $\rightarrow$ recipient] chimeras. In some experiments, $2 \times 10^{6} \mathrm{AKR}$ T-cell subsets obtained from untreated $(A K R \times B R)$ $F_{1}$ mice were introduced intravenously into $[B R \rightarrow$ BR] syngeneic BM chimeras one week after BMT. $[\mathrm{BR} \rightarrow \mathrm{BR}]$ chimera mice were prepared as described above.

\section{Cell purification}

Spleen cells were passed over nylon wool columns and the purified T-cells were treated with either anti-CD4 $\mathrm{mAb}$ or anti-CD8 $\mathrm{mAb}$ and selected rabbit $C$. These cells were further purified by $M-450$
Journal of Clinical and Experimental Hematopathology Vol. 41 No. 1

Dynabeads (Dynal Inc., Norway) coated with antirat immunoglobulin $\mathrm{G}$ ( $\mathrm{IgG})$ and anti-mouse $\mathrm{IgG}$ antibodies $(\mathrm{Ab})$. The purified cell fraction showed more than $99 \%$ relevant cells. The $\mathrm{CD}^{+}$and $\mathrm{CD}^{+}$ $\mathrm{T}$-cell fractions were then treated with anti-CD44 $\mathrm{mAb}$ and stained cells were sorted using the FACStar system as described elsewhere ${ }^{16}$.

\section{Flow cytometry}

Three-color FACS analyses were carried out as previously described ${ }^{17,18}$. Thymocytes from chimeric mice were treated in vitro before analysis with the following primary mAbs: anti-Thyl.1 (T11D7e. Olac), anti-CD3 $\varepsilon(2 \mathrm{C} 11)$, anti-V $\beta 6(44-22-1)$ or anti-V $\beta 8.1,2,3$ (F23.1). Biotinylated anti-mouse and anti-rat IgG secondary $\mathrm{Ab}$ (Cappel, West Chester, PA, USA) were also used, followed by TANDEM-streptavidin (Southern Biotech., Birmingham, AL, USA) to treat the thymocytes. After blockingbinding sites of these secondary $\mathrm{Ab}$, phycoerythrin (PE)-anti-CD4 and fluorescein isothiocyanate (FITC)-anti-CD8 (Becton-Dickinson, Mountain View, CA) were reacted with the thymocytes. When the population of host-derived T-cells was analyzed, cells were first incubated with biotinylated anti-mouse IgG followed by PEstreptavidin. Then, anti-Thyl.1 or anti-Thyl.2 $\mathrm{mAb}$ and FITC-anti mouse IgG were added. Stained cells were analyzed with a FACScan system (Becton-Dickinson).

\section{RNA preparation and PCR analysis of $M T V-7$}

Total cellular RNA was extracted from spleen cells using the guanidinium isothiocyanate method $^{19}$. Reverse-transcription (RT) was performed, and the Mls- ${ }^{a}$-specific sequence contained within the ORF of the 3'-LTR of MTV-7 cDNA was amplified $^{20}$ using the following Mls- ${ }^{\mathrm{a}}$-specific primers : 5'-primer GTCAAAGAACAGGTGCAAGGAC and 3'-primer AAGGGATCGAAGCCAACGCG. The $\beta$-Actin cDNA was amplified for control (5-primer TGGAATCCTGTGGCATCCATGAAAC and 3'-primer TAAAACGCAGCTCAGTAACAGTCCG).

\section{Mixed lymphocyte reaction (MLR)}

MLR was performed as described elsewhere ${ }^{11,16}$. BR T-cells were stimulated with AKR or $(A K R \times$ BR) $F_{1} T$-cell subsets in the presence of mitomycin- 
treated BR spleen cells as antigen-presenting cells (APC). In some experiments, $V \beta 8.2-\mathrm{T}$-cells of BR mice were used.

\section{Statistical analyses}

Statistical analyses were carried out using Student's $t$ test. $P$ values of less than 0.05 were considered significant.

\section{RESULTS}

\section{Effect of allogeneic BMT on leukemogenesis in SL mice}

The SL mouse, which develops pre- B-cell leukemia, was established in $\mathrm{Japan}^{21,22}$. It has been reported that allogeneic BMT prevents leukemogenesis in spontaneous and radiation-induced

A

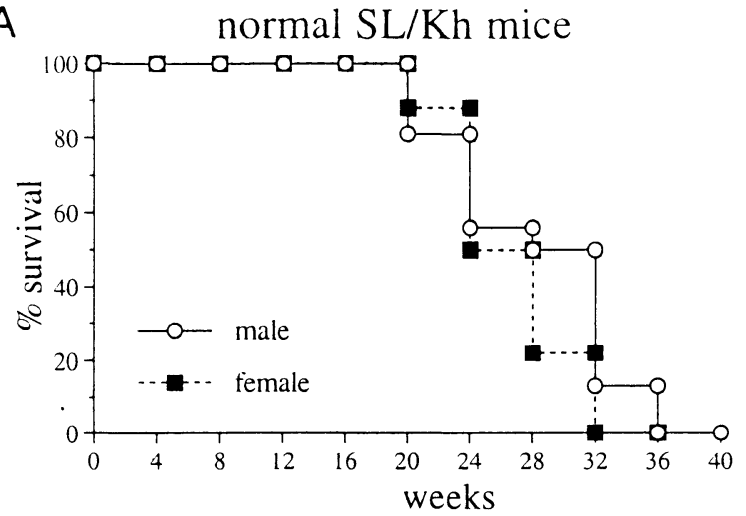

C 10Gy $[\mathrm{B} 6-->\mathrm{SL} / \mathrm{Kh}]$

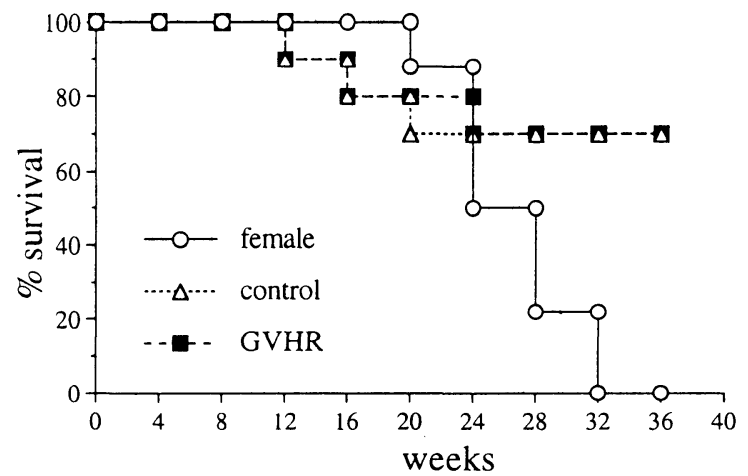

models ${ }^{13,22,23}$. Thus, we attempted to determine whether allogeneic BMT also prevents leukemogenesis in the SL mouse, a pre-B-cell leukemia model.

Fig. 1A shows that all non-treated SL mice died of leukemia within 36 weeks. No difference was observed between male and female mice. SL mice irradiated with a dose of $10 \mathrm{~Gy}$ and received syngeneic SL BM cells showed a survival pattern similar to non-treated SL mice (Fig. 1B). However, when allogeneic (B6) BM cells were transplanted to SL mice irradiated with doses of $10 \mathrm{~Gy}$ or $11 \mathrm{~Gy}$, approximately $70 \%$ or $50 \%$ of the mice, respectively, survived more than 36 weeks after BMT (Fig. C, D). No difference in the survival curve was detected between the $[\mathrm{B} 6 \rightarrow \mathrm{SL}]$ (control) and the GVHR [B6 $\rightarrow \mathrm{SL}$ ] chimeras.

B
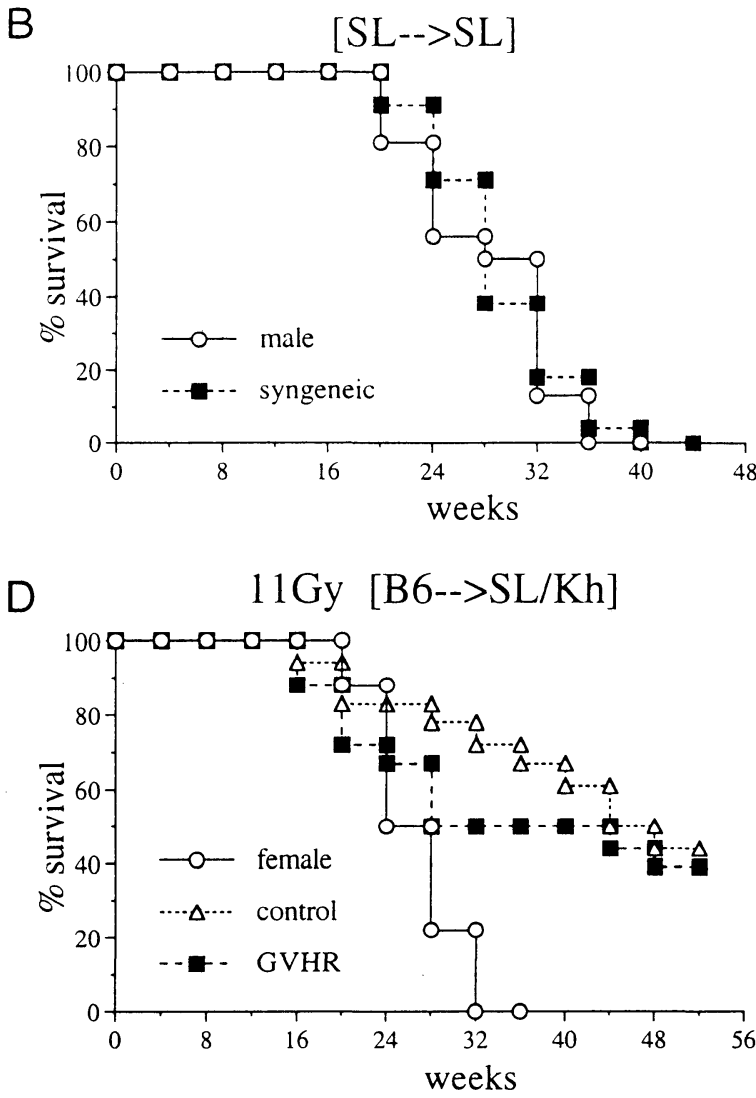

Fig. 1. Survival of $[\mathrm{B} 6 \rightarrow \mathrm{SL}]$ after BMT. SL recipient mice were lethally irradiated $(\mathrm{B}, \mathrm{C}: 10 \mathrm{~Gy}, \mathrm{D}: 11$ $\mathrm{Gy})$ and their self tolerance reconstituted with $2 \times 10^{7} \mathrm{BM}$ cells. A. Non-treated male $(\bigcirc)$ and female $(\boldsymbol{\square})$ mice. B. Syngeneic $[\mathrm{SL} \rightarrow \mathrm{SL}]$ male $(\bigcirc)$ and female $(\boldsymbol{\square})$ chimeras. C. SL mice irradiated with a dose of $10 \mathrm{~Gy}$, whose self tolerance was reconstituted with B6 BM cells pretreated with anti-Thyl. 2 plus $\mathrm{C}($ control $\triangle$ ) or B6 BM cells pretreated with anti-Thy1.2 alone (GVHRם). D. SL mice irradiated with a dose of $11 \mathrm{~Gy}$, whose self tolerance was reconstituted with B6 BM cells pretreated

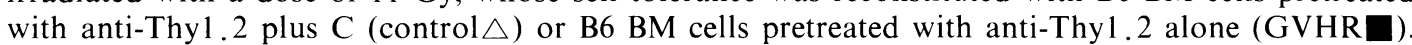
Survival curves of non-treated female mice $(\bigcirc)$ are also illustrated in $\mathrm{C}$ and $\mathrm{D}$ for comparison. 


\section{Elimination of $V \beta \sigma^{+}$T-cells in the $[\mathrm{D} 2 \rightarrow S L]$ and the $[\mathrm{D} 2 \rightarrow A K R]$ chimeras}

We reported that $\mathrm{V} \beta 6^{+} \mathrm{T}$-cells reactive to Mls$1^{\text {a }}$ plus MHC class II were eliminated in the thymus and the spleen of $[\mathrm{B} 10 . \mathrm{AQR} \rightarrow \mathrm{AKR}]$ and $[\mathrm{B} 10 . \mathrm{BR}$ $\rightarrow \mathrm{AKR}]$ chimeras as the result of negative selection $^{7,25}$. The elimination of $\mathrm{V} \beta 6^{+} \mathrm{T}$-cells, however, was abrogated in GVHR chimeras ${ }^{12,15,26}$. Since the SL background partially containsAKR genes, it was assumed that SL mice expressed $\mathrm{Mls}^{-} 1^{\mathrm{a}}$. Thus, we used RT-PCR to examine whether Mls- $1^{\text {a }}$ messages were present in SL cells or not. Fig. 2 shows that the $\mathrm{SL}$ mouse is an Mls-1 ${ }^{\mathrm{a}}$-positive strain. We next analyzed $\mathrm{V} \beta 6^{+} \mathrm{T}$-cells in $[\mathrm{D} 2 \rightarrow \mathrm{SL}]$ chimeras. We also reported that MHC class II molecules, especially $\mathrm{H}-2 \mathrm{E}$ must be present on the surface of $\mathrm{BM}$ -

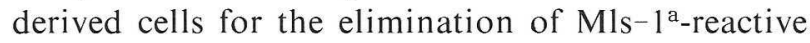
$\mathrm{T}$-cells. Thus, instead of $\mathrm{B} 6\left(\mathrm{H}-2 \mathrm{E}^{-}\right), \mathrm{D} 2$ mice $\left(\mathrm{H}^{-}\right.$ $2 \mathrm{E}^{+}$) were used as donors of BMT in this experiment. Table 1 shows that $\mathrm{V} \beta 6^{+} \mathrm{T}$-cells are eliminated from both the thymus and the lymph nodes (LN) of [D2 $\rightarrow \mathrm{SL}]$ chimeras as well as from the thymus of $[\mathrm{D} 2 \rightarrow$ $\mathrm{AKR}]$ chimeras. By contrast, in GVHR [D2 $\rightarrow \mathrm{SL}]$ chimeras, significant proportions of $\mathrm{V} \beta 6^{+} \mathrm{T}$-cells were detected in the thymus and $\mathbf{L N}$. This finding is consistent with the results obtained with the [D2 $\rightarrow$ AKR] chimeras (Table 1, and Refs. 12, 25).

Perhaps as was shown in [B10. AQR $\rightarrow$ AKR] chimeras $^{12,15,16,25}$, minor GVHR eradicated the radioresistant recipient cells that otherwise might have supplied Mls-1 $1^{\text {a }}$ molecules. Indeed, we found residual SL T-cells (20\%) in the LN of $[\mathrm{D} 2 \rightarrow \mathrm{SL}]$ chimeras, but only less than $2 \%$ in GVHR $[\mathrm{D} 2 \rightarrow \mathrm{SL}]$ chimeras 5 weeks after BMT. No B-cells of the recipient type were seen in either the control or GVHR chimeras. These findings are consistent with our previous reports with AKR chimeras ${ }^{11,15,25}$. A variation in the proportion of $\mathrm{V} \beta 8^{+} \mathrm{T}$-cells appeared to result from partial elimination of $\mathrm{V} \beta 8.1^{+}$ T-cells that also react with Mls- $1^{\text {a12 }}$. These findings taken together demonstrate that the major population supplying Mls- $1^{\text {a }} \mathrm{Ag}$ is the $\mathrm{T}$ lineage cells of SL recipient mice.

\section{Mls-1 $1^{\text {a }}$ producing $T$-cell subsets}

Prior findings suggested that radio-resistant recipient $\mathrm{T}$-cells produce Mls-1 ${ }^{\mathrm{a}}$. Using modified $M_{L R}{ }^{11}$. We next analyzed $T$-cell subsets that are responsible for the production of $\mathrm{Mls}^{-1}{ }^{\mathrm{a}}$. Since the $\mathrm{SL}$ mouse is from an $\mathrm{H}-2$ recombinant and their use

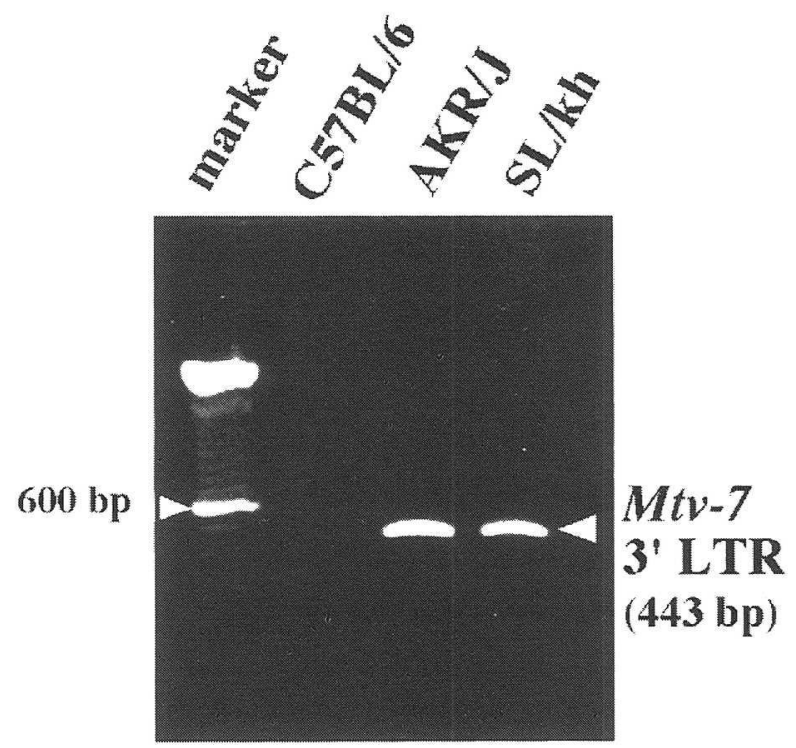

Fig. 2. Identification of Mls- 1 type of SL mice. Total RNA was isolated from spleen cells and reverse transcription PCR was performed with the primers specific for the 3'-LTR of $M T V-7$. Note the $M T V-7$ bands (443bp) in SL as well as in $\mathrm{AKR} / \mathrm{J}$ cells.

Table 1. Proportions of $\mathrm{V} \beta 6^{+}$and $\mathrm{V} \beta 8^{+}$cells in the thymus and the $\mathrm{LN}$ from allogeneic chimeras

\begin{tabular}{|c|c|c|c|c|c|c|}
\hline & \multicolumn{3}{|c|}{$\mathrm{CD}_{4}^{+} 8^{-}$} & \multicolumn{3}{|c|}{$\mathrm{CD}_{4}^{-} 8^{+}$} \\
\hline & CD3 & $\mathrm{Vb} 6 / \mathrm{CD} 3$ & $\mathrm{Vb} 8 / \mathrm{CD} 3$ & CD3 & $\mathrm{Vb6/CD3} \mathrm{V}$ & $\mathrm{Vb} 8 / \mathrm{CD} 3$ \\
\hline$[\mathrm{D} 2 \rightarrow \mathrm{SL}]$ & $\%$ & $\%$ & $\%$ & $\%$ & $\%$ & $\%$ \\
\hline thymus & 93 & 0 & 33 & 50 & 1 & 19 \\
\hline LN & 83 & 0 & 25 & 80 & 0 & 12 \\
\hline $\begin{array}{l}\text { GVHR }[\mathrm{D} 2 \rightarrow \mathrm{SL}] \\
\text { thymus }\end{array}$ & 98 & 4 & 36 & 86 & 10 & 27 \\
\hline LN & 72 & 9 & 43 & 52 & 6 & 56 \\
\hline $\begin{array}{l}{[\mathrm{D} 2 \rightarrow \mathrm{AKR}]} \\
\text { thymus }\end{array}$ & 96 & 2 & 21 & 64 & 1 & 25 \\
\hline $\begin{array}{l}\text { GVHR } \\
{[\mathrm{D} 2 \rightarrow \mathrm{AKR}]} \\
\text { thymus }\end{array}$ & 97 & 7 & 21 & 81 & 12 & 29 \\
\hline
\end{tabular}

*Pooled cells from 2 to 3 mice per group were analyzed. Representative data from 3 independent experiments are shown.

as stimulators in MLR presented a number of complications, we used $\mathrm{AKR}$ or $(\mathrm{AKR} \times \mathrm{BR}) \mathrm{F}_{1}$ cell as stimulators. Whole T-cells or a population of T-cell depleted of $\mathrm{V} \beta 8.2^{+}$cells from BR mice were cultured with syngeneic APC in the presence of the T-cell subsets from AKR mice. Table 2 shows that the proportion of $\mathrm{V} \beta 6^{+} \mathrm{T}$-cells increased significantly among blast cells of BR responders, in the presence of $\mathrm{CD} 8^{+} \mathrm{T}$-cells from AKR mice. No appre- 
ciable increase of $\mathrm{V} \beta 6^{+} \mathrm{T}$-cells was induced with AKR CD4 ${ }^{+} \mathrm{T}$-cells. Thus, the major population that produces $\mathrm{Mls}^{-1} \mathrm{Ag}$ is the $\mathrm{CD} 8^{+} \mathrm{T}$-cell fraction. Similar results were obtained with $(A K R \times B R) F 1$ stimulators (data not shown).

Next, AKR T-cells were further fractionated and analyzed in MLR. To activate only stimulator AKR T-cells, in this particular experiment, $\mathrm{V} \beta 8.2-$ $\mathrm{T}$-cells of BR mice were used as responders. Table 2 shows that $\mathrm{CD}_{4} 4^{+}$memory-type $\mathrm{T}$-cells of AKR mice vigorously stimulate BR T-cells as compared to $\mathrm{CD}_{4} 4^{-}$native T-cells. Furthermore, when the stimulatory cells were activated with immobilized anti-V $\beta 8.2 \mathrm{mAb}$, the proportions of responding $\mathrm{V} \beta 6^{+} \mathrm{T}$-cells were markedly increased. In this condition, even the $\mathrm{CD} 4^{+} \mathrm{CD} 44^{-}$stimulators generated considerable MLR. These findings are essentially compatible with our previous reports ${ }^{11,16}$.

Table 2. Proportions of $\mathrm{V} \beta 6^{+}$cells in BR blasts

\begin{tabular}{|c|c|c|c|}
\hline Stimulator & $\begin{array}{c}\text { Activation with } \\
\text { anti-V } \beta 8.2\end{array}$ & $\mathrm{~V} \beta 6$ & $\mathrm{~V} \beta 8.2$ \\
\hline$-\mathrm{a}$ & & $13.5 \pm 0.2 \%$ & $15.5 \pm 1.1 \%$ \\
\hline $\mathrm{CD}^{+} \mathrm{a}$ & - & $14.1 \pm 1.2$ & $15.3 \pm 1.2$ \\
\hline $\mathrm{CD} 4^{+} \mathrm{CD} 44^{+} \mathrm{b}$ & - & $24.1 \pm 0.4^{* *}$ & ND \\
\hline $\mathrm{CD} 4^{+} \mathrm{CD} 44^{+} \mathrm{b}$ & + & $30.5 \pm 0.1^{* *}$ & ND \\
\hline $\mathrm{CD} 4^{+} \mathrm{CD} 44^{-} \mathrm{b}$ & - & $14.2 \pm 0.5$ & ND \\
\hline $\mathrm{CD} 4^{+} \mathrm{CD} 44^{-} \mathrm{b}$ & + & $21.2 \pm 1.1^{* *}$ & ND \\
\hline $\mathrm{CD} 8^{+} \mathrm{a}$ & - & $27.0 \pm 1.2^{*}$ & $10.5 \pm 0.7$ \\
\hline $\mathrm{CD} 8^{+} \mathrm{CD} 44^{+} \mathrm{b}$ & - & $34.1 \pm 0.1^{* *}$ & ND \\
\hline $\mathrm{CD} 8^{+} \mathrm{CD} 44^{+} \mathrm{b}$ & + & $62.0 \pm 1.2^{* *}$ & ND \\
\hline $\mathrm{CD} 8^{+} \mathrm{CD} 44^{-} \mathrm{b}$ & - & $22.5 \pm 1.9^{* *}$ & ND \\
\hline $\mathrm{CD} 8^{+} \mathrm{CD}^{-} 4^{-} \mathrm{b}$ & + & $22.6 \pm 1.5^{* *}$ & ND \\
\hline
\end{tabular}

a : BR T-cells were stimulated with T-cell subsets from AKR mice in the presence of BR APC. Each number represents the mean proportion of $\mathrm{V} \beta 6^{+} / \mathrm{CD}^{+}$or $\mathrm{V} \beta 8^{+} / \mathrm{CD}^{+} \pm \mathrm{SD}$ of triplicate cultures. A representative result from three separate experiments is shown. *Significantly higher than control without stimulators $(\mathrm{p}<0.001)$.

$\mathrm{b}$ : Proportions of $\mathrm{V} 6^{+} / \mathrm{CD}^{+}$were calculated in the responder $\mathrm{V} \beta 8.2^{-}$blast cells from BR mice after coculture with stimulator T-cell subsets from AKR mice in the presence of BR APC. **Significantly higher than control value without stimulators $(12.5 \pm 0.1 \%)(\mathrm{p}<0.01)$.

\section{Clonal elimination of $\mathrm{V} \boldsymbol{\sigma}^{+} \mathrm{T}$-cells in $[\mathrm{BR} \rightarrow$ $B R]$ syngeneic chimeras after administration of $(A K R \times B R) F_{1} T$-cell subsets}

We next intravenously administrated subsets of $\mathrm{T}$-cells from $(\mathrm{AKR} \times \mathrm{BR}) \mathrm{F}_{1}$ mice into $[\mathrm{BR} \rightarrow \mathrm{BR}]$ chimeras, one week after BMT. Six weeks after administration of $(\mathrm{AKR} \times \mathrm{BR}) \mathrm{F}_{1} \mathrm{~T}$-cells, proportions of $\mathrm{V} \beta 6^{+} \mathrm{T}$-cells in the thymus and $\mathrm{LN}$ were analyzed by flowcytometry. Table 3 shows that administration of $\mathrm{CD} 8^{+} \mathrm{CD} 44^{+} \mathrm{T}$-cells resulted in significant decreases of $\mathrm{V} \beta 6^{+} \mathrm{T}$-cells in both the thymus and the $\mathrm{LN}$ of $[\mathrm{BR} \rightarrow \mathrm{BR}]$ miceas if $\mathrm{CD}^{+}$ $\mathrm{CD}_{4}{ }^{+} \mathrm{T}$-cells were present in the $[\mathrm{BR} \rightarrow \mathrm{BR}]$ thymus and $\mathrm{LN}$. We reported that $\mathrm{CD} 8^{+} \mathrm{CD} 44^{+}$ AKR T-cells, which had been inoculated into $[\mathrm{BR} \rightarrow$ $B R$ ] mice one week after BMT, were present in the thymus even at later stages ${ }^{16}$.

Inoculation of $\mathrm{CD}^{+} \mathrm{CD}^{-} 4^{-} \mathrm{T}$-cells of $(\mathrm{AKR} \times$ BR) $F_{1}$ mice reduced the proportion of $V \beta 6^{+} \mathrm{T}$-cells only in the $\mathrm{LN}$ of chimeras. Administration of $\mathrm{CD}^{+} \mathrm{T}$-cells subsets showed no reduction of $\mathrm{V} \beta 6^{+}$ $\mathrm{T}$-cells at all. These findings are consistent with the results obtained with MLR and our previous study in which the T-cell repertoire was analyzed at later periods after $\mathrm{BMT}^{16}$. The present results indicate again that $\mathrm{CD} 8{ }^{+} \mathrm{CD} 44^{+} \mathrm{T}$-cells are the most potent Mls-1a - producing cells.

\section{DISCUSSION}

BMT is one of the most promising therapies for many hematopoietic and immunodeficiency diseases that can not otherwise be treated effectively ${ }^{27,28}$. In the present study, we showed that allogeneic BMT prevented leukemogenesis in SL mice, an animal model for spontaneous pre- B-cell leukemia, as was shown in $\mathrm{AKR} / \mathrm{J}$ mice, an animal model for spontaneous thymic lymphoma ${ }^{13,24}$. It has been reported

Table 3. Proportion of $\mathrm{V} \beta 6^{+} \mathrm{T}$-cells in the thymus and the $\mathrm{LN}$ of $[\mathrm{BR} \rightarrow \mathrm{BR}]$ syngenic chimeras

\begin{tabular}{lcccc}
\hline \multirow{2}{*}{$\begin{array}{l}\text { T-cell subsets } \\
\text { administered }\end{array}$} & \multicolumn{4}{c}{ Thymus LN } \\
\cline { 2 - 5 } & $\mathrm{CD}^{+} 8^{-}$ & $\mathrm{CD} 4^{-} 8^{+}$ & $\mathrm{CD}^{+}$ & $\mathrm{CD}^{+}$ \\
\hline -a $^{\mathrm{a}}$ & $7.8 \pm 0.5$ & $13.1 \pm 0.8$ & $7.5 \pm 0.3$ & $12.3 \pm 0.4$ \\
$\mathrm{CD}^{-} \mathrm{CD}^{+} 4^{+}$ & $7.8 \pm 0.2$ & $13.3 \pm 0.3$ & $6.9 \pm 0.3$ & $11.5 \pm 0.4$ \\
$\mathrm{CD}^{+} \mathrm{CD} 44^{-}$ & $7.5 \pm 0.1$ & $13.5 \pm 0.1$ & $7.5 \pm 0.4$ & $12.5 \pm 0.5$ \\
$\mathrm{CD} 8^{+} \mathrm{CD} 44^{+}$ & $3.0 \pm 0.4^{*}$ & $2.8 \pm 1.5^{*}$ & $2.0 \pm 0.1^{*}$ & $2.9 \pm 1.0^{*}$ \\
& $7.3 \pm 0.1$ & $12.0 \pm 0.1$ & $5.0 \pm 0.1^{*}$ & $7.1 \pm 0.0^{*}$ \\
\hline
\end{tabular}

$(\mathrm{AKR} \times \mathrm{BR}) \mathrm{F}_{1} \mathrm{~T}$-cell subsets $\left(2 \times 10^{5}\right)$ were injected intravenously into $[\mathrm{BR} \rightarrow \mathrm{BR}]$ syngenic chimeras 1 week after BMT. Six weeks after reconstitution, FACS analyses were carried out.

Data show mean \pm SD of 3 mice per each group.

${ }^{a}$ No Fl T-cells were injected (control).

* Significantly lower than control value $(\mathrm{p}<0.01)$. 
that GVHR may exert beneficial influences on the reconstitution of recipient hematopoietic and lymphoid tissues by donor-derived cells (graft enhancement ${ }^{29,30}$. In addition, GVHR may be associated with graft versus leukemia $(G V L)$ effect $^{31}$. However, we could not detect any appreciable influences of minor GVHR on the survival of SL chimeras in the conditions we tested. Similar survival curves were observed in the control and the GVHR $[\mathrm{B} 6 \rightarrow \mathrm{SL}]$ chimeras.

We have reported that minor GVHR resulted in the abrogation of negative selection of $\mathrm{T}$-cells reactive to recipient $\mathrm{Ag}^{12,15,25,26}$. In the $\mathrm{SL}$ chimera system, we also found that minor GVHR led to the failure of clonal elimination of $\mathrm{Mls}^{-} \mathrm{I}^{\mathrm{a}}$-reactive T-cells. At first, the abrogation of the negative selection was attributed to the lack of Mls-1 ${ }^{\text {a }}$ Agproducing cells in GVHR $\left[\mathrm{Mls}-1^{\mathrm{b}} \rightarrow \mathrm{Mls}^{-} \mathrm{1}^{\mathrm{a}}\right]$ chimeras. However, we found recently that GVHR resulted in the failure of clonal elimination of T-cells reactive to donor $\mathrm{Ag}^{32}$.

Thus, itmay be concluded that the GVHR also induces functional changes to the thymus. Similar observation was reported by Desbarats and Lapp ${ }^{33}$.

We reported that the acute GVHR induced in AKR recipients shifted the $T$-cell responses to the Th2 dominant state ${ }^{34}$. This early Th2 shift appeared to be associated with the subsequent $\mathrm{T}$-cell responsiveness, since T-cells recovered from acute GVHR showed the Th2 dominant state. Thus, T-cells from such chimeras prominently producedIL-4 but not IFN- $\gamma$ upon stimulation. In addition, these T-cells exhibited significant MLR but not cytotoxic Tlymphocyte responses to the recipient $\mathrm{Ag}$ (split tolerance $)^{35}$. Although we did not analyze T-cell responsiveness in $[\mathrm{B} 6 \rightarrow \mathrm{SL}]$ chimeras, a similar functional state appeared to be generated in these GVHR chimeras., since significant proportions of $\mathrm{Mls}^{-} \mathrm{1}^{\mathrm{a}}$ reactive $\mathrm{T}$-cells were detected in GVHR $[\mathrm{D} 2 \rightarrow \mathrm{SL}]$ mice but not in control $[\mathrm{D} 2 \rightarrow \mathrm{SL}]$ chimeras. We first expected that these Mls- ${ }^{\mathrm{a}}$-reactive $\mathrm{T}$-cells might be exerting the GVL effect. However, as described above, no difference was observed in the survival rate between $[\mathrm{B} 6 \rightarrow \mathrm{SL}]$ and $\mathrm{GVHR} \quad[\mathrm{B} 6 \rightarrow \mathrm{SL}]$ chimeras. It is possible that these $\mathrm{Mls}-1^{\mathrm{a}}$-reactive T-cells induced neither harmful GVHR responses nor beneficial GVL responses in GVHR $[\mathrm{B} 6 \rightarrow \mathrm{SL}]$ chimeras. It seems important to elucidate the basic mechanism underlying the immunological alteration induced by GVHR in further studies.

In the present study, we demonstrated that the major population of $\mathrm{Mls}-1^{\mathrm{a}}$-producing cells of the recipients were $\mathrm{CD} 8^{+} \mathrm{CD} 44^{+} \mathrm{T}$-cells, although these findings were obtained with the AKR chimera system but not with the SL chimera system. These findings are essentially compatible with our previous reports $^{11,16,25}$. In our previous studies ${ }^{11,16}$, we demonstrated that $\mathrm{CD}^{+} \mathrm{CD}^{+} 4^{+} \mathrm{T}$-cells expressed larger amounts of $M T V-7$ mRNA than $\mathrm{CD}^{+} \mathrm{CD}^{+} 4^{-}$ T-cells. Since cells of donor mice cannot produce Mls $-1^{\mathrm{a}}$, it is clear that Mls- ${ }^{\mathrm{a}} \mathrm{Ag}$ derived from radio-resistant recipient cells (mainly $\mathrm{CD} 8^{+} \mathrm{CD} 44^{+}$) are transferred to and presented on the surface of donor MHC class $\mathrm{II}^{+}$cells in the thymus (crosspresentation). We and others have reported that these Mls-1a Ag plus MHC class II on the surface of donor BM-derived cells (APC) eliminate the Mls$1^{\mathrm{a}}$-reactive $\mathrm{T}$-cells between 2 and 3 weeks after BMT in the thymic medulla ${ }^{7,9,10}$.

Although we analyzed here $\mathrm{T}$-cell reactivities to a superantigen, GVHR appears to be induced by various allogeneic protein Ags including MHC Ag. It is now understood that the major GVHR is not induced by the recipient $\mathrm{MHC} \mathrm{Ag}$ alone but by complexes of $\mathrm{MHC}$ and peptide $\mathrm{Ag}$ bound in the Ag-binding groove of the $\mathrm{MHC}^{36,37}$. These recipient peptides with a specific motif for binding to the $\mathrm{MHC}^{38}$ appeared to be derived from cellular components of the recipient. Thus, identification of the peptide Ag involved in the rather complex GVHR is essential to explain the influence of the GVHR on the development of the recipient immune system, especially a state tolerant to the recipient $\mathrm{Ag}$. The determination of the peptide Ag also leads to elucidation of the tissue injury induced by T-cells specific for the peptide Ag.

\section{ACKNOWLEDGMENTS}

We thank Ms. Kaori Kohno for her secretarial assistance. This study was supported in part by a Grant-in-Aid for Scientific Research by the Ministry of Education, Science, Sports and Culture, Japan, Research on Immunology, Allergy and Organ Transplantation, Ministry of Health and Welfare, Japan, Nishimura Aging Fund and The Tomakomai East Hospital Foundation.

\section{REFERENCES}

1 Reinisch CL, Litman GW: Evolutionary immunobiology. Immunol Today 10: 278-281, 1989

2 MacDonald HR, Schneider R, Lees RK, Howe RC, Acha-Orbea H, Festenstein H, Zinkernagel RM, 
Hengartner $\mathrm{H}$ : T-cell receptor $\mathrm{Vb}$ use predicts reactivity and tolerance to Mlsa-encoded antigen. Nature 332: 40-45, 1988

3 Abe R, Hodes RJ : T-cell recognition of minor lymphocyte stimulating (Mls) gene products. Annu Rev Immunol 7: 683-708, 1989

4 Herman A, Kappler JW, Marrack P, Pullen AM : Superantigens: mechanism of $\mathrm{T}$-cell stimulation and role in immune responses. Annu Rev Immunol 9: 745-772, 1991

5 Janeway CA Jr: Selective elements for the $\mathrm{Vb}$ region of the T-cell receptor: Mls and the bacterial toxic mitogenes. Adv Immunol 50: 1-53, 1991

6 Marrack P, Kushnir E, Kappler J : A maternally inherited superantigen encoded by a mammary tumor virus. Nature 349: 524-526, 1991

7 Fukushi N, Wang B, Arase H, Ogasawara K, Good $\mathrm{RA}$, Ono $\mathrm{K}$ : Cell components required for deletion of an auto-reactive T-cell repertoire. Eur J Immunol 20: 1153-1160, 1990

8 Arase H, Arase N, Ogasawaea K, Good RA, Ono $\mathrm{K}$ : Clonal elimination of self reactive $\mathrm{Vb6}^{+} \mathrm{T}$-cells induced by $\mathrm{H}-2$ products expressed on thymic radio-resistant components. Int Immunol 4: 75-82, 1992

9 Speiser DE, Chvatchko Y, Zinkernagel RM, MacDonald HR: Distinct fate of self-specific T-cells developing in irradiation bone marrow chimeras: clonal deletion, clonal anergy, or in vitro responsiveness to self-Mls- $1^{\text {a }}$ controlled by hemopoietic cells in the thymuses. J Exp Med 172: 1305-1314, 1990

10 Yoshikai Y, Ogimoto M, Matsumoto K, Sakumoto M, Matsuzaki G, Nomoto K : Deletion of Mlsreactive T-cells in $\mathrm{H}-2$ compatible but Mlsincompatible bone marrow chimeras. Eur $\mathrm{J}$ immunol 19: 1009-1013, 1989

11 Arase-Fukushi N, Arase H, Wang B, Ogasawara K, Good RA, Ono K: Production of minor lymphocyte stimulatory- $1^{\mathrm{a}}$ antigen from activated $\mathrm{CD}^{+}$or $\mathrm{CD}^{+}$T-cells. J Immunol 151: $4445-$ 4454, 1993

12 Fukushi N, Arase H, Wang B, Ogasawara K, Gotohda T, Good RA, Ono K: Thymus, a direct target tissue in graft versus host reaction after allogeneic bone marrow transplantation which results in abrogation of induction of self-tolerance. Proc Natl Acad Sci USA 87: 6301-6305, 1990

13 Ono K, Fernandes G, Good RA: Humoral and cell-mediated immune responses in fully allogeneic bone marrow chimera in mice. J Exp Med 151: 115-132, 1980

14 Ono K, Yasumizu R, Oh-ishi T, Kakinuma M, Good RA, Fernandes G, Morikawa K: Specific elimination of the $\mathrm{T}$ lineage cells : Effect of in vitro treatment with anti-Thy-1 serum without complement on the adoptive cell transfer system. J Immunol Methods 49 : 315-322, 1982

15 Arase-Fukushi N, Arase H, Wang B, Hirano M, Ogasawara K, Good RA, Ono K : Influence of a small number of mature $\mathrm{T}$-cells in donor bone marrow inocula on reconstitution of lymphoid tissues and negative selection of a T-cell repertoire in the recipient. Microbiol Immunol 37: 883-894, 1993

16 Arase N, Arase H, Takayanagi T, Mishima M, Iwabuchi K, Ogasawara K, Ono K : Production of minor lymphocyte stimulatory- $1^{\text {a }}$ antigens from T-cell subsets. Immunobiol 193: 378-390, 1995

17 Iwabuchi C, Iwabuchi K, Nakagawa K, Takayanagi T, Nishihori H, Tone S, Ogasawara K, Good RA, Ono $\mathrm{K}$ : Intrathymic selection of $\mathrm{NK} 1.1^{+} \mathrm{a} / \mathrm{b}$ $\mathrm{T}$-cell antigen receptor $(\mathrm{TCR})^{+}$cells in transgenic mice bearing TCR specific for chicken ovalbumin and restricted to I-A ${ }^{\mathrm{d}}$. Proc Natl Acad Sci USA 95 : 8199-8204, 1998

18 Iwabuchi K, Iwabuchi C, Tone S, Itoh D, Tosa N, Negishi I, Ogasawara K, Uede T, Ono K : Defective development of $\mathrm{NK} 1.1^{+} \mathrm{T}$-cell antigen receptor (TCR) $\mathrm{ab}^{+}$cells in zeta-associated protein (ZAP) null mice with an accumulation of NK1.1+ CD3NK-like cells in the thymus. Blood, (in press)

19 Chomczynski P, Sacchi N : Single-step method of RNA isolation by acid guanidinium thiocyanatephenol-chloroform extraction. Anal Biochem 162 : 156-159, 1987

20 Sambrook J, Fritsch EF, Maniatis T: In Molecular Cloning: A Laboratory Manual. Vol. 1. Cold Spring Harbor Laboratory Press, Cold Spring Harbor, NY. 1989

21 Shimada MO, Yamada Y, Nakakuki Y, Okamoto K, Fukumoto M, Honjo T, Hiai H : SL/KH strain of mice : a model of spontaneous pre-B-lymphomas. Leukemia Res 17: 573-578, 1993

22 Hiai H, Kaneshima H, Nakamura H, Oguro YB, Moriwaki K, Nishizuka Y: Unusually early and high rate of spontaneous occurrence of nonthymic leukemia in $\mathrm{SL} / \mathrm{Kh}$ mice, a subline of $\mathrm{SL}$ strain. Jpn J Cancer Res 73: 704-712, 1982

23 Aizawa S, Sado T: Graft-versus-leukemia effect in MHC-compatible and incompatible allogeneic bone marrow transplantation of radiation-induced, leukemia-bearing mice. Transplantation 52:885889,1991

24 Tanaka T, Obata Y, Fernandes G, Ono K, Stockert E, Good RA : Prevention of leukemia in lethally irradiated AKR mice by CBA-H marrow transplantation. Proc Am Assoc Cancer Res 20: 114, 1979 (Abstr.).

25 Hirano M, Arase H, Arase-Fukushi N, Ogasawara 
K, Iwabuchi K, Miyazaki T, Good RA, Ono K : Reconstitution of lymphoid tissues under the influence of subclinical level of graft versus host reaction induced by bone marrow T-cells or splenic T-cell subsets. Cell Immunol 151 : 118-132, 1993

26 Ono K, Arase N, Arase H, Takayanagi T, Nishihori $\mathrm{H}$, Iwabuchi K, Ogasawara K, Good RA : Influence of graft versus host reaction on the $\mathrm{T}$-cell repertoire differentiating from bone marrow precursors following allogeneic bone marrow transplantation. Transplant Immunol 5: 75-82, 1997

27 Good RA : Toward safer marrow transplantation. New Eng J Med 306: 421-423, 1982

28 Good RA, Kapoor N, Reisner Y : Bone marrow transplantation - an expanding approach to tretment of many diseases. Cell Immunol 82: 36-54, 1983

29 Sykes M, Sheard MA, Sachs DH : Effects of T-cell depletion in radiation bone marrow chimeras II. Requirement for allogeneic $\mathrm{T}$-cells in the reconstituting bone marrow inoculum for subsequent resistance to breaking tolerance. J Exp Med 168 : 661-673, 1988

30 Murphy WJ, Kumar V, Cope JC, Bennett M : An absence of T-cells in murine bone marrow allografts leads to an increased susceptibility to rejection by natural killer cells and T-cells. J Immunol 144 : 3305-3311, 1990

31 Horowitz MM, Gale RP, Sondel PM, Goldman JM, Kersey J, Kolb HJ, Rim AA, Ringden O, Rozman C, Speck B: Graft-versus-leukemia reactions after bone marrow transplantation. Blood 75: 555-562, 1990

32 Morohashi T, Ogasawara K, Kitaichi N, Iwabuchi $\mathrm{K}$, Ono $\mathrm{K}$ : Abrogation of negative selection by GVHR induced by minor histocompatibility antigens or $\mathrm{H}-2 \mathrm{D}$ antigen alone. Immunobiol 202 : $368-379,2000$

33 Desbarats J, Lapp WS: Thymic selection and thymic major histocompatibility complex class II expression are abnormal in mice undergoing graftversus-host reaction. J Exp Med 178: 805-814, 1993

34 Takayanagi T, Nishihori H, Matsuki N, Iwabuchi $\mathrm{K}$, Ogasawara K, Ono K: Effects of non-major histocompatibility antigens on acute graft-versushost reaction after allogeneic bone marrow transplantation. Bone Marrow Transplant 20 : 297-304, 1997

35 Morohashi T, Ogasawara K. Kitaichi N, Iwabuchi $\mathrm{K}$, Ono $\mathrm{K}$ : Significant MLR but not CTL responses against recipient antigens generated in $\mathrm{T}$-cells from bone marrow chimeras recovered from GVHD. Bone Marrow Transplant 26 : 1069-1076, 2000

36 den Haan JMM, Sherman NE, Blokland E, Huczko E, Koning F, Drijfhout JW, Skipper J, Shabonowitz $\mathrm{J}$, Hunt DF, Engelhard VH: Identification of a graft versus host disease-associated human minor histocompatibility antigen. Science 268: 14761480, 1995

37 Leibnitz RR, Lipsky PL, Thiele DL: Protection from $T$ helper cell mediated graft-versus-host disease by the presence of an MHC class I alloantigen is associated with perturbation of MHC class IIrestricted responses by class I-derived peptide. J Immunol 155 : 1784-1795, 1995

38 Ogasawara K, Ono K: MHC binding motifs and design of peptide-based vaccines. Trends Microbiol $1: 276-279,1993$ 